\title{
Peningkatan dan Perbaikan dari Temuan Audit External ISO 9001 di LP3I College
}

\author{
Wiwiet Prihatmadji \\ Administrasi Bisnis, Politeknik LP3I Jakarta \\ Email : wpmadji@gmail.com
}

$\begin{array}{ll}\text { ARTICLE INFO } & \text { ABSTRACT } \\ \text { Keywords: } & \text { The findings of external audits in order to ensure the implementation of ISO } 9001 \\ \text { ISO 9001, } & \text { quality management system at LP3I College for three consecutive years provide } \\ \text { PDCA } & \text { management system in accordance with applicable requirements. The methodology } \\ \text { SOP } & \text { used refers to the PDCA methodology as a model for running the management process } \\ \text { (NCR) Conformance } & \text { weporth continuous improvement. Improved system in the stages of the Plan in the form of } \\ & \text { Management of quality objectives, analysis and evaluation, as well as back up data. } \\ & \text { Stage of Do in the form of maintenance evaluation and realization of infrastructure } \\ & \text { and facilities targets, and Special Basic Skills Ability is set as a reference for the new } \\ & \text { admissions graduation Criteria. Stages of Check in the form of monitoring and } \\ & \text { evaluation of Quality Achievements by the leader of his subordinates, analysis and } \\ & \text { evaluation of customer satisfaction. The Act Stages are an evaluation of the } \\ & \text { effectiveness of Improvement Measures from the Non Conformance Report (NCR) } \\ \text { findings, and makes corrective actions against any non-achievement of quality } & \text { objectives. Corrections in the implementation of QMS as a solution of the findings by } \\ \text { the auditor in the case of nonconformance of internal standards for Plan stage: } \\ \text { document validation, re-examination of SOP content, and Evaluation on Outsourcing. } \\ \text { For the cycle of Do: supplier evaluation responsibilities. While Check cycle: } \\ \text { establishing observation findings as Auditor Suggestions or alternative improvements. } \\ \text { Whereas the inconsistency actions that must be controlled so that they are always } \\ \text { consistent in carrying out procedures include, stage of Plan : mapping each official } \\ \text { according to his competence, stage of Do: the entire course and the recording, and } \\ \text { stage of Check: the period of analysis and evaluation of customer satisfaction at least } \\ \text { once a year. }\end{array}$

\section{PENDAHULUAN}

Hampir semua organisasi sacara aktif berusaha untuk meningkatkan kualitas produk atau jasanya. Sistem manajemen mutu (SMM) merupakan salah satu alternatif sistem untuk peningkatan kualitas berdasarkan persyaratan ISO 9001. Standar ISO 9001 mensyaratkan organisasi untuk melakukan audit internal di interval yang direncanakan untuk menilai kesesuaian penerapan sistem manajemen mutu dengan standar internal dan eksternal. Sedangkan sertifikat ISO 9001 diperoleh setelah organisasi menjalani proses audit eksternal dari badan sertifkasi. Audit eksternal adalah audit yang dilakukan oleh badan sertifikasi ISO yang bersifat independen, bukan dari lingkungan organisasi. Audit yang dilakukan oleh tim di organisasi sendiri disebut audit internal. Audit eksternal pada tahun pertama untuk medapatkan sertifikasi disebut audit sertifikasi, sedangkan untuk tahun kedua dan ketiga distebut audit surveillance.

LP3I College sejak tahun 2009 telah menerapkan sistem manajemen mutu dengan dijalankannya proses audit sertifikasi, dilanjutkan dengan proses audit Surveillance pertama di tahun 2010 dan proses audit Surveillance kedua di tahun 2011. Hasil temuan dari proses audit eksternal selama tiga tahun berturut-turut telah memberikan pengaruh yang positif terhadap peningkatan, perbaikan, dan konsistensi penerapan sistem manajemen mutu sesuai dengan persyaratan yang berlaku.

Dengan diterapkannya Sistem Manajemen Mutu ISO 9001di LP3I College, diharapkan bahwa institusi akan selalu memberikan produk dan pelayanan yang terbaik, dan selalu berkomitmen terhadap mutu. Bukti dari kualitas institusi, adanya peningkatan, perbaikan, dan konsistensi penerapan sistem manajemen mutu sesuai dengan persyaratan yang berlaku. Hal inilah yang menjadi dasar bagi peneliti dalam menyusun 
penelitian ini dengan judul : "Peningkatan dan Perbaikan dari Temuan Audit External ISO 9001 di LP3I College".

\section{Identifikasi Masalah}

Audit External oleh Badan Sertifkasi Independen merupakan salah satu syarat yang harus dipenuhi oleh organisasi untuk mendapatkan sertifikasi ISO 9001. LP3I College yang telah memperoleh sertifikasi ISO 9001 sejak tahun 2009, dan tetap memperbaharui hingga kini, tentu telah melaksanakan proses audit external setiap tahun. Proses krusial dalam rangka memperoleh pengakuan internasional Sistem Manajemen Mutu ISO 9001 adalah mempersiapkan organisasi untuk siap menjalankan proses audit oleh Badan Sertifikasi Independen.

Kesuksesan LP3I College dalam implementasi ISO 9001, dengan pelaksanaan audit external oleh badan sertifikasi independen dalam tiga tahun berturut-turut menunjukkan tahapan implimentasi dan kontrol kinerja yang terbukti sesuai dengan persyaratan ISO 9001, telah meng-inspirasi penulis untuk membuat penelitian dengan judul: "Peningkatan dan Perbaikan dari Temuan Audit External ISO 9001:2008 di LP3I College".

Berdasarkan judul tersebut diatas, maka penulis mengidentifikasikan masalah pada :

1. Apa saja Temuan Audit External ISO 9001:2008 yang terlaksana di LP3I College ?

2. Langkah Perbaikan apa saja yang terhadap Temuan Audit External ISO 9001:2008 di LP3I College ?

3. Bagaimana solusi dari masalah-masalah yang dihadapi oleh LP3I College dalam Peningkatan dan Perbaikan terhadap Temuan Audit External ISO 9001:2008?

\section{METODOLOGI PENELITIAN}

Merujuk kepada Sokovic et. al (2010) dengan menggunakan metodologi PDCA sebagai model untuk menjalankan proses manajemen dengan perbaikan berkelanjutan. PDCA berisikan empat tahapan berulang untuk mencapai perbaikan berkelanjutan, yaitu: Plan (Perencanaan), Do (Pelaksanaan), Check / Study (Pengawasan / Pembelajaran) dan Act (Aksi). ISO Sekertariat (2008) menyatakan bahwa PDCA digunakan sebagai acuan penyusunan Standard Quality Management System ISO 9001.

Siklus PDCA efektif digunakan dalam melakukan pekerjaan dan mengelola program kerja. Di dalam siklus PDCA memungkinkan untuk melakukan dua jenis tindakan perbaikan yaitu perbaikan yang bersifat sementara dan permanen. Tindakan sementara untuk bertujuan mengatasi dan memperbaiki masalah secara praktis. Sedangkan tindakan perbaikan permanen, yang terdiri dari analisis dan menghilangkan akar penyebab untuk mencapai target proses perbaikan terus-menerus (Sukovic et. al, 2010).

ISO Sekertariat (2009) telah mempublikasikan hubungan siklus PDCA dengan SMM yang dapat dilihat dalam Gambar 3.

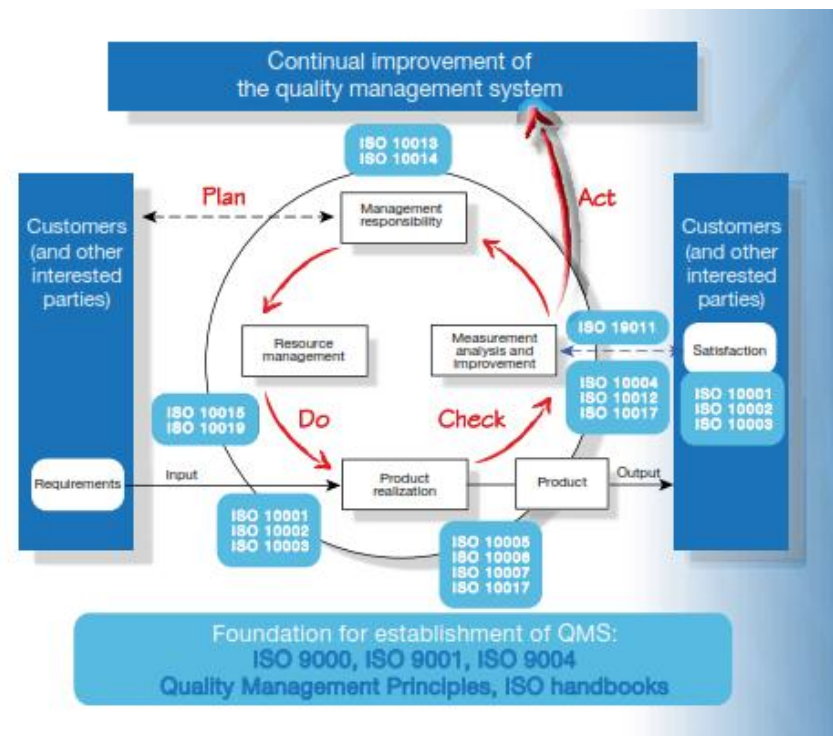

Gambar 3. Hubungan Siklus PDCA dengan Sistem Manajemen Mutu ISO 9001.

Wiwiet Prihatmadji, et.al.( Peningkatan dan Perbaikan dari Temuan Audit External ISO 9001...) 


\section{Pembatasan Penelitian}

Objek penelitian adalah LP3I College yang beralamat di J1. Kramat Raya No 7/9, Jakarta Pusat. Data primer yang digunakan sebagai bahan analisa adalah laporan Non Conformance Report dari hasil audit external pada perode sertifikasi tahun 2009, dan Audit Surveillance tahun pertama 2010, dan audit surveillance tahun kedua 2011.

\section{LANDASAN TEORI}

\subsection{Pengertian Sistem Manajemen Mutu ISO 9001:2008}

\subsubsection{Sistem Manajemen Mutu ISO 9001 (SMM)}

Menurut Graeme Knowles (2011) Sistem Manajemen Mutu merujuk kepada kebijakan organisasi dalam mengelola proses atau kegiatan, sehingga produk atau jasa yang dihasilkan dapat memenuhi tujuan yang telah dicanangkan oleh organisasi itu sendiri, seperti:

1. Memenuhi kualifikasi pelanggan,

2. Memenuhi peraturan perundang-undangan, atau

3. Tercapainya sasaran organisasi.

Columbus (2000) menerangkan bahwa ISO 9001 merupakan standar internasional yang mengatur tentang Sistem Manajemen Mutu (Quality Management System) dimana prinsip dasarnya adalah "control" terhadap semua aspek yang dapat mempengaruhi mutu. ISO 9001 dikeluarkan oleh International Organization for Standarization. ISO 9001 pertama dikeluarkan pada tahun 1987.

ISO 9001 bertujuan untuk menjamin konsistensi organisasi dalam menghasilkan produk yang bermutu yang dapat memuaskan pelanggannya. Untuk tujuan tersebut, ISO 9001 berisi persyaratanpersyaratan mengenai bagaimana organisasi harus mengendalikan berbagai proses yang dapat mempengaruhi mutu, baik langsung maupun tidak langsung. Persyaratan tersebut pada dasarnya adalah sandaran dari praktek-praktek bisnis yang sudah diakui oleh dunia industri efektif dalam upaya penjaminan mutu (Ann Terlaak dan Andrew A King, 2012).

ISO 9001 bersifat umum atau generik. Persyaratan-persyaratan yang ada di dalamnya dapat diaplikasikan oleh berbagai jenis organisasi, besar atau kecil, manufaktur atau jasa, swasta maupun badan pemerintah. Setiap organisasi dapat memilih pendekatan dan cara yang paling sesuai bagi organisasinya dalam menerapkan persyaratan-persyaratan tersebut, sepanjang maksud dan tujuan dari persyaratan dapat tercapai (Graeme Knowles, 2011).

Sekertariat ISO hingga tahun 2008 telah menerbitkan 4 ( empat ) versi, yaitu : versi tahun 1987, 1994, 2000 dan versi 2008. Untuk versi 2008 terdiri dari 3 (tiga) standar yaitu : ISO 9000 (yang berisi definisi kata yang digunakan dalam ISO 9001), ISO 9001 (yang berisi persyaratan sistem manajemen mutu - standar inilah yang dapat dikontraktual atau disertifikasi oleh badan sertifikasi) dan ISO 9004 (berisi acuan untuk meningkatkan penerapan ISO 9001).

\subsection{Pengertian Audit menurut ISO 9001}

Menurut ISO 9000:2005, Fundamentals and vocabulary of Quality management systems, Audit adalah: "serangkaian kegiatan yang sistematis, independen, dan terdokumentasi untuk memperoleh bukti audit (audit evidence) dan mengevaluasinya secara objektif untuk menentukan sejauh mana kriteria audit (audit criteria) terpenuhi. “

Standar ISO 9001 (tentang Standar Sistem Manajemen Mutu) dan ISO 19011 (tentang Panduan Audit Internal) menekankan pentingnya audit sebagai perangkat manajemen untuk memantau dan melakukan verifikasi efektivitas penerapan kebijakan organisasi terhadap mutu. Audit juga merupakan bagian penting dari kegiatan penilaian kesesuaian seperti sertifikasi/registrasi eksternal dan evaluasi rantai pasokan (supply chain) serta pengawasan.

Dalam Pandun Sistem Manajemen Mutu ISO 9001:2008, Klausul 8.2.2 menyatakan bahwa Organisasi harus melakukan audit internal pada selang waktu terencana untuk menentukan bahwa: a) sistem manajemen mutu telah memenuhi standar organisasi, baik standard internal maupun external, dan 
b) sistem manajemen mutu telah diterapkan dan dipelihara secara efektif. Program audit harus direncanakan, dengan mempertimbangkan status serta pentingnya proses dan area yang diaudit, termasuk hasil audit sebelumnya. Kriteria, lingkup, frekuensi dan metode audit harus ditetapkan. Pemilihan auditor dan pelaksanaan audit harus memastikan keobjektifan dan ketidakberpihakan proses audit. Auditor tidak boleh mengaudit pekerjaan mereka sendiri. Prosedur terdokumentasi harus ditetapkan untuk mendefiniskan tanggung jawab dan persyaratan untuk perencanaan dan pelaksanaan audit, penetapan rekaman dan pelaporan hasil. Rekaman audit dan hasilnya harus dipelihara (Klausul 4.2.4). Manajemen yang bertanggung jawab atas area yang diaudit harus memastikan bahwa setiap perbaikan dan tindakan perbaikan yang perlu dilakukan tanpa ditunda untuk menghilangkan ketidaksesuaian dan penyebab ketidaksesuaian yang ditemukan. Kegiatan tindak lanjut harus mencakup verifikasi tindakan yang dilakukan dan pelaporan hasil verifikasi (Klausul 8.5.2).

ISO telah menerbitkan Panduan Audit Sistem Manajemen Mutu/Lingkungan, yaitu ISO 19011, yang memberikan panduan untuk pengelolaan program audit, pelaksanaan audit internal atau eksternal terhadap sistem manajemen mutu dan/atau lingkungan, serta kompetensi dan evaluasi auditor. Panduan ini dimaksudkan dapat berlaku untuk calon pengguna yang beragam, termasuk auditor, organisasi yang menerapkan sistem manajemen mutu dan/atau lingkungan, organisasi yang perlu melaksanakan audit sistem manajemen mutu dan/atau lingkungan karena persyaratan kontrak, dan organisasi yang bergerak dalam bidang sertifikasi atau pelatihan auditor, dalam sertifikasi/registrasi sistem manajemen, dalam akreditasi atau dalam standardisasi di bidang penilaian kesesuaian.

Menurut Panduan ISO 19011 program audit terbagi dalam:

a. Audit internal yang terkadang disebut audit pihak pertama, dilaksanakan oleh, atau atas nama organisasi itu sendiri untuk kaji ulang manajemen dan tujuan internal lainnya, dan dapat menjadi dasar untuk "Pernyataan Diri Kesesuaian Organisasi". Dalam beberapa hal, khususnya untuk organisasi skala kecil, independensi dapat diperagakan melalui kebebasan tanggung jawab auditor dari kegiatan yang diaudit.

b. Audit eksternal mencakup audit yang biasanya disebut dengan audit pihak kedua dan pihak ketiga.

$\checkmark$ Audit pihak kedua dilaksanakan oleh pihak yang memiliki kepentingan terhadap organisasi, seperti pelanggan, atau personel lain atas nama pelanggan.

$\checkmark$ Audit pihak ketiga dilaksanakan oleh organisasi eksternal yang melakukan audit secara independen, seperti organisasi yang memberikan registrasi atau sertifikasi kesesuaian terhadap persyaratan ISO 9001:2008.

c. Bila sistem manajemen mutu dan sistem manajemen lingkungan diaudit secara bersamaan, audit ini disebut audit kombinasi.

d. Bila dua atau lebih organisasi audit bekerjasama dalam mengaudit satu auditi disebut audit gabungan.

Dalam Klausal 4 Standar ISO 19011 diterangkan bahwa, Audit didasarkan pada sejumlah prinsip sebagai alat yang efektif dan dapat diandalkan dalam mendukung kebijakan dan pengendalian manajemen serta memberikan informasi bagi organisasi untuk dapat meningkatkan kinerjanya. Kepatuhan terhadap prinsip tersebut merupakan prasyarat untuk memberikan kesimpulan audit yang sesuai dan cukup serta memungkinkan auditor bekerja secara independen untuk mencapai kesamaan kesimpulan pada situasi yang serupa.

Dalam Klausal 5.2.2 ISO 19011, diterangkan mengenai variasi dari cakupan program audit yang dapat dipengaruhi oleh ukuran, sifat dan kompleksitas dari organisasi yang diaudit, serta beberapa hal berikut:

a) ruang lingkup, tujuan dan jangka waktu dari setiap audit yang dilaksanakan;

b) frekuensi pelaksanaan audit;

c) jumlah, kepentingan, kompleksitas, kemiripan dan lokasi dari kegiatan yang diaudit;

d) standar, peraturan perundang-undangan dan persyaratan kontrak serta kriteria audit lainnya; e) kebutuhan untuk akreditasi atau sertifikasi/registrasi; 
f) kesimpulan dari audit sebelumnya atau hasil dari tinjauan program audit sebelumnya;

g) isu bahasa, budaya dan sosial;

h) perhatian pihak yang berkepentingan;

i) perubahan yang signifikan pada suatu organisasi atau operasinya.

\subsection{Penelitian Terdahulu}

Penelitian tentang implementasi SMM di perusahaan dan institusi pendidikan telah banyak di paparkan di jurnal internasional maupun local. Hendartho (2014) melaporkan implementasi Sistem Manajemen Mutu di Institut STIAMI berjalan dengan baik berdasarkan analisa klausul-klausul Sistem Manajemen Mutu (klausul 4), Tanggung jawab Manajemen (klausul 5), Realisasi Produk (klausul 7), Pengukuran, Analisis \& Peningkatan (klausul 8) dan Manajemen Sumber Daya (klausul 5). Mangula (2013) melaporkan adanya peningkatan kualitas dan kuantitas kinerja perusahaan manufacturing di Tanzania dari perusahaan-perusahaan yang mendapatkan sertifikasi SMM. Sedangkan Sumeidi dan Nurcahyo (2011) melaporkan motif PTS di Banten dalam menerapkan ISO 9001 : 2008 pada lingkup administrasi adalah motif eksternal sementara rancangan sistem manajemen mutunya bersifat minimalis untuk memenuhi persyaratan SNI ISO 9001 : 2008 saja. Diaye et.al (2008) melaporkan dua kendala yang dihadapi oleh perusahaan manufacturing dan jasa di Serbia-Montenegro dalam implementasi SMM, yaitu efektivitas pelatihan dan efisiensi fasilitas infrastruktur. Santos dan Millan (2012) mempresentasikan motivasi dan manfaat perusahaan-perusahaan di Portugis yang mengimplementasikan SMM. Motivasi utamanya adalah peningkatan kualitas (improvement of quality), media pemasaran (marketing advantage), dan pemangkasan pembiayaan (cost reduction). Manfaat yang diperoleh berupa perbaikan prosedur (the improvement of procedures),peningkatan kepuasan pelanggan (increase of the customer satisfaction), dan menurunnya biaya produksi (decrease of production costs).

Penelitian dengan pembahasan khusus tentang audit SMM juga telah banyak dipublikasikan. Naukowe (2012) meneliti bahwa peningkatan kualitas audit internal akan lebih efektif jika dilakukan langkah berikut: a. topik audit yang fleksibel dan difahami oleh auditor, b. team auditor yang fleksibel, dapat memadukan antara rencana audit dengan kesiapan auditee, c. rencana audit tahunan yang dikonsultasikan dengan auditee. Sementara Rogala (2015) menemukan bahwa audit inernal tidak dilaksanakan dengan optimal terhadap implementasi SMM pada dua belas pusat penjernihan air di Polandia, yang dibuktikan dari rata-rata pelaksanaan tindakan perbaikan (corrective action) hanya berjumlah kurang dari lima dalam setiap tahun. Dalam publikasi yang lain, Rogala (2015) mendapatkan kegagalan audit inernal disebabkan karena: ketidak cakapan auditor, tidak adanya alokasi waktu untuk mempersiapkan audit, dan rendahnya kesadaran auditee dan pimpinan terhadap fungsi audit. Prihatmadji telah meneliti tentang implementasi SMM di LP3I College (2014) dan kesesuain dokumentasi di LP3I College dengan standar ISO 9001. (2017).

\section{PEMBAHASAN}

National Security Inspectorate UK (2016) menerbitkan interpretasi siklus PDCA pada ISO 9001:2015 dipadukan dengan korelasi marix antara ISO 9001 versi 2008 dan 2015 (ISO Sekertariat 2015) menghasilkan siklus PDCA pada SO 9001:2008 seperti tertera dalam Tabel 1.

\section{Tabel 1.}

Korelasi Matriks PDCA dan ISO 9001

dengan keterangan warna highlight teks.

Plan :Highlight teks tidak berwarna untuk klausul 4, 5, 6 dan 7 dari ISO 9001:2015.

Do : Highlight teks berwarna abu-abu muda untuk klausul 8 dari ISO 9001:2015.

Check : Highlight teks berwarna abu-abu tua, dengan teks putih untuk klausul 9 dari ISO 9001:2015.

Action : Highlight teks berwarna hitam, dengan teks putih hijau untuk klausul 10 dari ISO 9001:2015. 


\begin{tabular}{|c|c|}
\hline PDCA & Klausul ISO 9001:2008 \\
\hline Plan & $\begin{array}{l}\text { Scope, 1.1 General, 1.2 Application, } 4 \text { Quality management system, } 4.1 \text { General } \\
\text { requirements, 4.2 Documentation requirements, 4.2.1 General, 4.2.2 Quality manual, } \\
4.2 .3 \text { Control of documents, } 4.2 .4 \text { Control of records, } 4.2 .3 \text { Control of documents, } 4.2 .4 \\
\text { Control of records, } 5 \text { Management responsibility, 5.1 Management commitment, 5.1 } \\
\text { Management commitment, 5.2 Customer focus, 5.3 Quality policy, 5.4.1 Quality objectives } \\
\text { 5.4.2 Quality management system planning, 5.5.1 Responsibility and authority, 5.5.2 } \\
\text { Management representative, 5.5.3 Internal communication, 5.6 Management review, } 6 \\
\text { Resource management, 6.1 Provision of resources, 6.1 Provision of resources, 6.2.1 } \\
\text { General, 6.2.2 Competence, training and awareness, } 6.3 \text { Infrastructure, 6.4 Work } \\
\text { environment, 7.6 Control of monitoring and measuring equipment, No equivalent clause, } \\
\text { 8.5.3 Preventive action. }\end{array}$ \\
\hline Do & 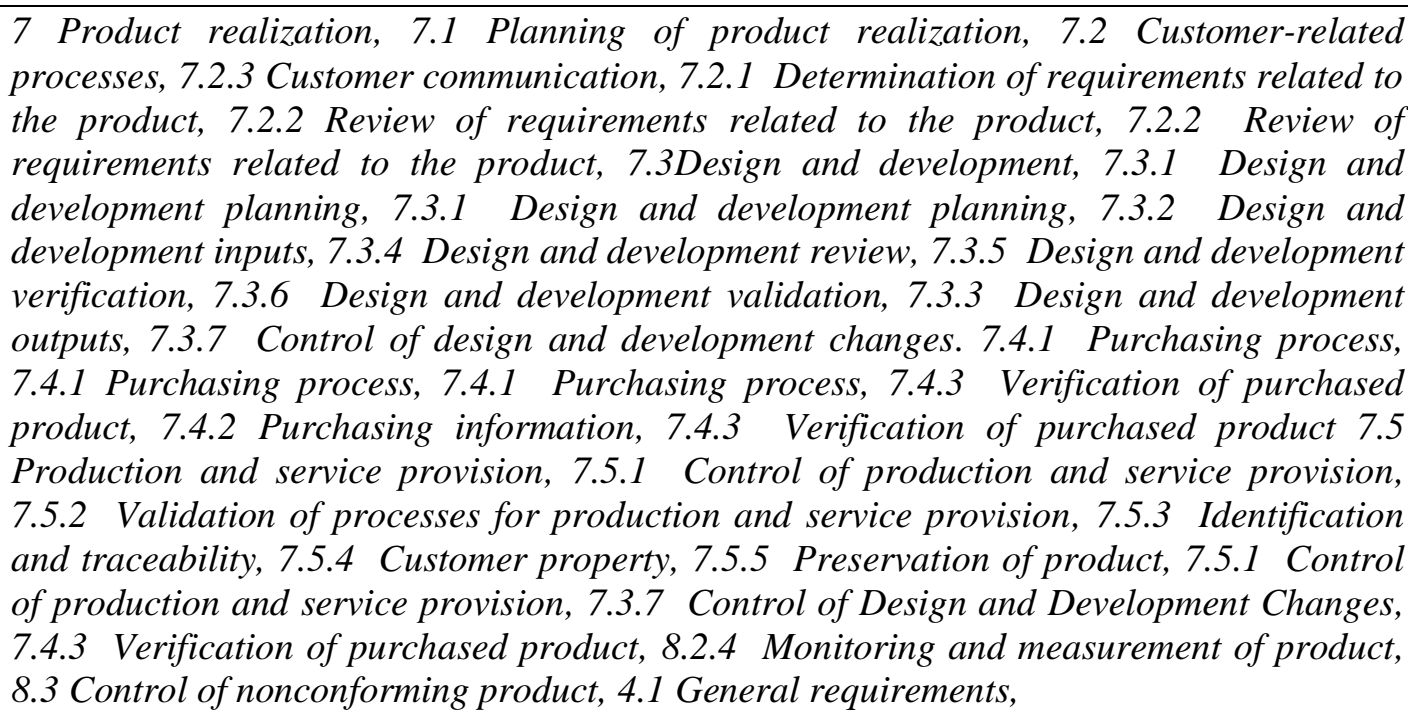 \\
\hline Check & $\begin{array}{l}\text { 8 Measurement, analysis and improvement, } 8 \text { Measurement, analysis and improvement, } \\
\text { 8.1 General, 8.2.3 Monitoring and Measurement Processes, 8.2.1 Customer satisfaction, } \\
\text { 8.4 Analysis of data, 8.2.2 Internal audit, 5.6 Management review, 5.6.1 General, } \\
\text { 5.6.2. Review input, 5.6.3 Review output }\end{array}$ \\
\hline Act & nprovement, 8.J.3 \\
\hline
\end{tabular}

Data primer tentang Perbaikan dari Temuan Audit Eksternal ISO 9001:2008 di LP3I College diperoleh dari Laporan Wakil Manajemen (Management Representative) sebagai tindakan perbaikan dari hasil temuan auditor external dalam tiga tahun berturut-turut, yaitu tahun 2009, 2010 dan 2011 yang tercantum dalam Tabel 2 hingga 4.

Tabel 2. Laporan Ketidaksesuaian

dari Hasil Audit Eksternal di LP3I College pada tanggal 11 April 2009.

\begin{tabular}{|c|c|c|c|c|}
\hline $\begin{array}{c}\text { PDC } \\
\mathrm{A}\end{array}$ & Ref & Nonconformity (Auditee) & Corrective Action ${ }^{l}$ & $\begin{array}{c}\text { Completio } \\
n \text { date }\end{array}$ \\
\hline$P$ & 5.6 .2 & $\begin{array}{l}\text { Capaian Sasaran Mutu (Quality } \\
\text { objective) tidak menjadi agenda } \\
\text { dalam Management Review (point } \\
\text { kinerja proses dan kesesuaian } \\
\text { produk) (QMR). }\end{array}$ & 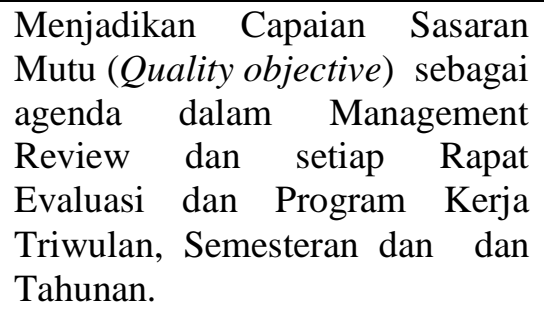 & $\begin{array}{c}21-04- \\
2009\end{array}$ \\
\hline
\end{tabular}




\begin{tabular}{|c|c|c|c|c|}
\hline $\mathrm{P}$ & 6.2 .2 & $\begin{array}{l}\text { Dua Pejabat masing-masing di HRD } \\
\text { dan Dosen Informatika Komputer } \\
\text { tidak sesuai dengan kompetensi } \\
\text { jabatannya. (HRD - QMR). }\end{array}$ & $\begin{array}{l}\text { Management Representative } \\
\text { mengawasi HRD membuat } \\
\text { mapping setiap pejabat dengan } \\
\text { kompetensi yang dipersyaratkan, } \\
\text { dan membuat program untuk } \\
\text { meningkatkan kompetensi } \\
\text { pejabat terkait yang tidak } \\
\text { memenuhi persyaratan. }\end{array}$ & $\begin{array}{r}05-05- \\
2009\end{array}$ \\
\hline $\mathrm{P}$ & 7.4 .1 & $\begin{array}{l}\text { Tidak ada metoda evaluasi terhadap } \\
\text { outsourced company untuk program } \\
\text { Table Manner dan Beauty Class } \\
\text { (Education). }\end{array}$ & $\begin{array}{l}\text { Mempersiapkan } \quad \text { Prosedur } \\
\text { Evaluasi Pelaksanaan Kegiatan } \\
\text { Penunjang (Outsourcing). }\end{array}$ & $\begin{array}{c}\text { Date }^{1}: \\
27-04- \\
2009\end{array}$ \\
\hline D & 7.4.1 & $\begin{array}{l}\text { Evaluasi Supplier tidak dijalankan } \\
\text { sesuai dengan klausul 7.4.1 yang } \\
\text { tertulis bahwa assesment dan } \\
\text { approval oleh Finance Director. }\end{array}$ & $\begin{array}{l}\text { Merevisi redaksi Evaluasi } \\
\text { Supplier oleh pimpinan setiap } \\
\text { bidang yang menjalankan proses } \\
\text { pembelian dan pengadaan } \\
\text { barang. }\end{array}$ & $\begin{array}{l}\text { Date }^{1}: \\
\text { 05-05- } \\
2009\end{array}$ \\
\hline $\mathrm{D}$ & 8.2.4 & $\begin{array}{l}\text { Organisasi tidak menjelaskan secara } \\
\text { jelas tentang Product Monitoring di } \\
\text { dalam Pedoman Mutu Klausul 8.2.4. }\end{array}$ & $\begin{array}{l}\text { Menjelaskan Product Monitoring } \\
\text { dalam Klausul 8.2.4 Bab } 8 \\
\text { halaman } 4 \text { dengan melalui audit } \\
\text { opersional cabang oleh Team } \\
\text { Operasional Pusat minimal satu } \\
\text { kali dalam setiap tahun dengan } \\
\text { mereferensikan SOP dan } \\
\text { JUKNIS tentang Audit } \\
\text { Operasional Cabang. }\end{array}$ & $\begin{array}{l}\text { Date }^{1}: \\
21-04- \\
2009\end{array}$ \\
\hline $\mathrm{C}$ & 8.4 & $\begin{array}{l}\text { Tidak dilakukan analisa terhadap } \\
\text { kepuasan pelanggan terhadap } \\
\text { Perusahaan Relasi yang telah MOU } \\
\text { dan membuat Repeat Order (C\&P). }\end{array}$ & $\begin{array}{l}\text { Melakukan analisa terhadap } \\
\text { kepuasan pelanggan dan } \\
\text { menjelaskan metodanya. }\end{array}$ & $\begin{array}{c}\text { Date }^{1}: \\
05-05- \\
2009\end{array}$ \\
\hline
\end{tabular}

Tabel 3. Laporan Ketidaksesuaian dari

Hasil Audit Eksternal di LP3I College pada tanggal 13 April 2010.

\begin{tabular}{|c|c|c|c|c|}
\hline PDCA & Ref & Nonconformity (Auditee) & Corrective Action $^{1}$ & $\begin{array}{c}\text { Completion } \\
\text { date }\end{array}$ \\
\hline $\mathrm{P}$ & 4.2 .3 & $\begin{array}{lr}\text { Pengendalian } & \text { eksternal } \\
\text { dokumen belum dilakukan } \\
\text { sesuai dengan internal } \\
\text { prosedur QP-QMR-00-02 } \\
\text { Pengendalian } r \text { Dokumen } \\
\text { rev.1 tertanggal } 29.04 .2009 \\
(\text { QMR). }\end{array}$ & $\begin{array}{l}\text { Melakukan validasi dokumen, baik } \\
\text { dokumen internal maupun eksternal, } \\
\text { yang ditandai / diberikan tanda cap } \\
\text { Validasi Dokument. Untuk dokumen } \\
\text { yang tidak berlaku lagi diberi tanda } \\
\text { pengenal dengan cap Expired } \\
\text { Document. }\end{array}$ & $\begin{array}{c}\text { Date }^{1}: \\
23.04 .20 \\
10\end{array}$ \\
\hline
\end{tabular}




\begin{tabular}{|c|c|c|c|c|}
\hline $\mathrm{P}$ & 4.2 .4 & $\begin{array}{l}\text { Hasil analisa data kepuasan } \\
\text { pelanggan belum bisa } \\
\text { ditunjukkan karena } \\
\text { tersimpan dalam soft copy } \\
\text { di komputer dan saat ini } \\
\text { kondisi hardware komputer } \\
\text { sedang rusak. Tidak ada } \\
\text { back up data baik dalam } \\
\text { bentuk soft copy maupun } \\
\text { hard copy yang tersedia } \\
\text { (Education). }\end{array}$ & 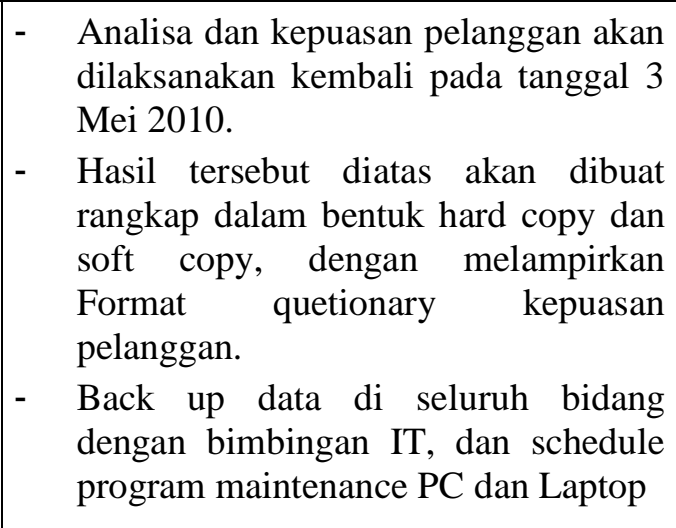 & $\begin{array}{l}\text { Date }^{1} \text { : } \\
\text { 03 Juni } \\
2010\end{array}$ \\
\hline $\mathrm{D}$ & 6.3 & $\begin{array}{l}\text { Program pemeliharaan dan } \\
\text { pelaksanaan belum } \\
\text { dilakukan untuk beberapa } \\
\text { prasarana seperti AC, } \\
\text { Gedung dan Penerangan } \\
\text { (GA). }\end{array}$ & $\begin{array}{l}\text { Program pemeliharaan \& pelaksanaan } \\
\text { terhadap prasarana akan dirinci untuk } \\
\text { setiap unit prasarana. }\end{array}$ & $\begin{array}{l}\text { Date }^{1} \text { : } \\
23 \text { April } \\
2010\end{array}$ \\
\hline C & 8.2.2 & $\begin{array}{l}\text { Implementasi prosedur } \\
\text { internal audit belum berjalan } \\
\text { secara konsisten, tidak } \\
\text { semua observasi (misal } \\
\text { temuan di area program) di } \\
\text { pindahan ke formulir } \\
\text { ketidaksesuaian, } \\
\text { sebagaimana di } \\
\text { persyaaratkan prosedur } \\
\text { Internal Audit QP-QMR-00- } \\
\text { 04. Serta tidak adanya } \\
\text { formulir ketidaksesuaian } \\
\text { yang dimaksud (QMR). }\end{array}$ & $\begin{array}{l}\text { Merevisi QP-QMR-00-04, tindak lanjut } \\
\text { dari temuan ketidak sesuaian dengan } \\
\text { menggunakan Form Non Conformance } \\
\text { Report (NCR). Sedangkan temuan } \\
\text { observasi sebagai saran auditor di tidak } \\
\text { lanjuti dengan tidak menggunakan } \\
\text { Form NCR, tetapi sebagai alternatif } \\
\text { perbaikan. Observasi digunakan } \\
\text { sebagai saran auditor atau alternatif } \\
\text { perbaikan. }\end{array}$ & $\begin{array}{l}\text { Date }^{1}: \\
23.05 .20 \\
10\end{array}$ \\
\hline A & 8.5.2 & 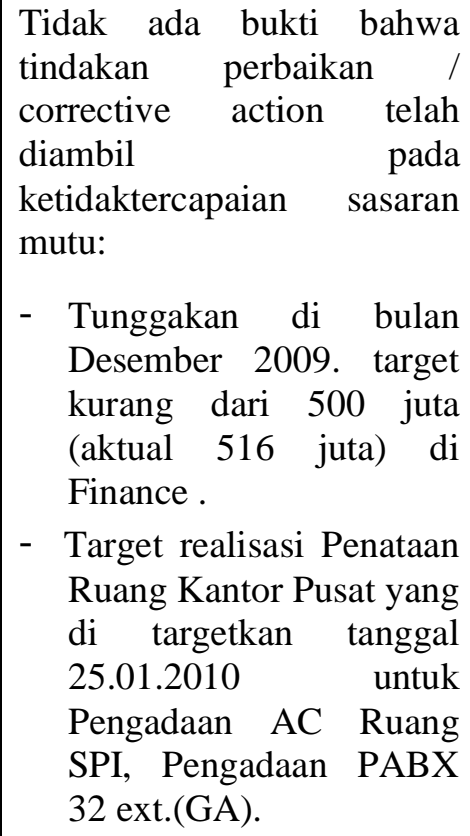 & $\begin{array}{l}\text { Dept. Finance: } \\
\text { 1. Proses penagihan dilakukan lebih } \\
\text { awal } \\
\text { 2. Pembayaran kewajiban cabang ke } \\
\text { Kantor Pusat selambat-lambatnya } \\
\text { pada tanggal } 15 \\
\text { 3. Tagihan cabang yang akan jatuh } \\
\text { tempo pada Bulan Desember } \\
\text { dilakukan proses penagihan pada } \\
\text { Minggu ke II atau ke III di bulan } \\
\text { Desember. } \\
\text { Dept. C\&BD-GA: } \\
\text { Target realisasi Penataan Ruang Kantor } \\
\text { Pusat yang pada bulan Mei 2010. } \\
\text { Pengadaan AC Ruang SPI, Pengadaan } \\
\text { PABX } 32 \text { ext pada bulan Agustus 2010. }\end{array}$ & $\begin{array}{l}\text { Date }^{1} \text { : } \\
30 \text { Mei } \\
2010\end{array}$ \\
\hline
\end{tabular}




\begin{tabular}{|c|c|c|c|c|}
\hline A & $\begin{array}{c}8.5 .2 \\
. f\end{array}$ & 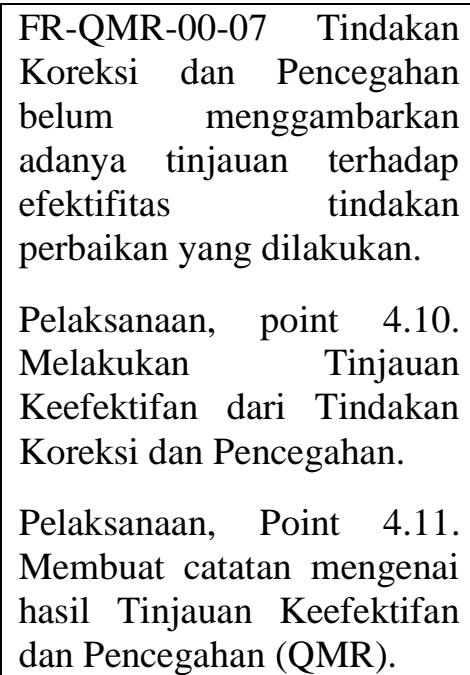 & 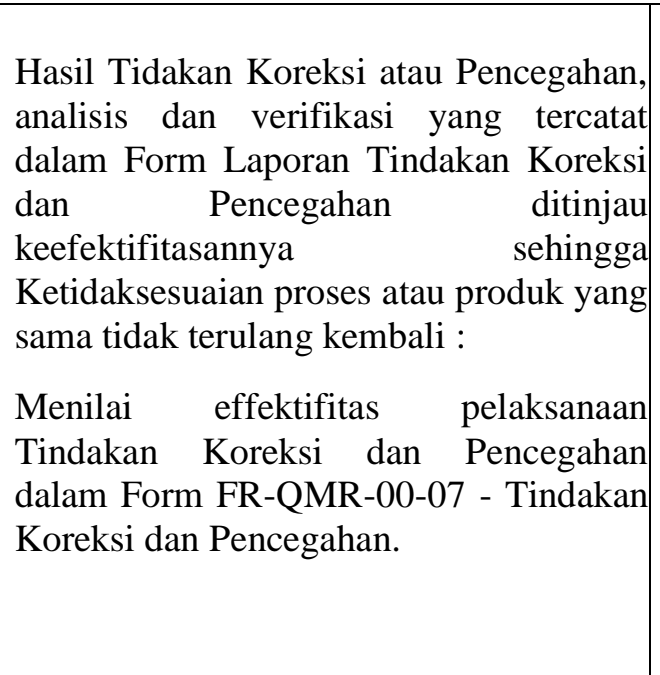 & $\begin{array}{c}\text { Date }^{1}: \\
23.05 .20 \\
10\end{array}$ \\
\hline
\end{tabular}

Tabel 4. Laporan Ketidaksesuaian

dari Hasil Audit Eksternal di LP3I College pada tanggal 11 Mei 2011.

\begin{tabular}{|c|c|c|c|c|}
\hline PDCA & $\operatorname{Ref}$ & Nonconformity (Auditee) & Corrective Action $^{l}$ & $\begin{array}{c}\text { Completion } \\
\text { date }\end{array}$ \\
\hline $\mathrm{P}$ & 5.4 .1 & $\begin{array}{l}\text { Tidak dapat dipastikan } \\
\text { sasaran mutu Direktorat } \\
\text { C\&BD: } \quad \text { Konsepsi } \\
\text { Pengembangan Lembaga } \\
\text { dan Penguatan LP3I } \\
\text { dapat terukur (C\&BD) }\end{array}$ & $\begin{array}{l}\text { Setiap Direksi, Eksekutif, Pimpinan } \\
\text { Cabang,Kepala Bagian wajib menyusun } \\
\text { Sasaran Mutu, Program Kerja } \\
\text { berdasarkan SMART (Specific, } \\
\text { Measurement, Applicable, Reasonable } \\
\text { dan Timeline). Sasaran Mutu dilengkapi } \\
\text { dengan startegi cara pencapaian. }\end{array}$ & $\begin{array}{c}\text { Date }^{1}: \\
16.05 .2011\end{array}$ \\
\hline $\mathrm{P}$ & 4.2 .3 & $\begin{array}{l}\text { Terdapat } r \text { kesalahan } \\
\text { dalam hal identifikasi } \\
\text { Dokumen eksternal pada } \\
\text { SOP No. PRC-10-033 } \\
\text { rev 0 tentang referensi } \\
\text { PP Waralaba harusnya } \\
\text { no. } \underline{42} \text { tahun } 2007 \text { tertulis } \\
\text { no. } \underline{24}(\mathrm{C} \& \mathrm{BD}) .\end{array}$ & $\begin{array}{l}\text { Akan dilakukan revisi SOP untuk } \\
\text { cetakan tahun } 2012 \text { terhadap kesalahan } \\
\text { dalam hal isinya kata demi kata setelah } \\
\text { dilakukan re-check content SOP terbitan } \\
\text { tahun terkini. }\end{array}$ & $\begin{array}{c}\text { Date }^{1}: \\
16.05 .2011\end{array}$ \\
\hline $\mathrm{D}$ & 7.1 & $\begin{array}{l}\text { Kriteria Kelulusan untuk } \\
\text { Kemampuan } \\
\text { Management pada saat } \\
\text { seleksi penerimaan } \\
\text { mahasiswa baru belum } \\
\text { ditetapkan r untuk } \\
\text { program } \\
\text { (Marketing). }\end{array}$ & 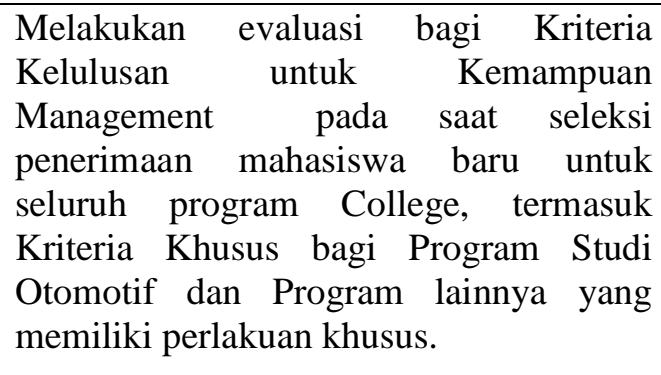 & $\begin{array}{c}\text { Date }^{1} \text { : } \\
\text { 19.05.2011 }\end{array}$ \\
\hline
\end{tabular}




\begin{tabular}{|c|c|c|c|c|}
\hline D & 7.5.1 & $\begin{array}{l}\text { Tidak ditemukan bukti } \\
\text { Laporan Kegiatan } \\
\text { Perkuliahan untuk kuliah } \\
\text { ke 7, program studi: } \\
\text { Business Administration, } \\
\text { Kelas: BA-02-135 } \\
\text { (Education). }\end{array}$ & $\begin{array}{l}\text { Melakukan evaluasi terhadap seluruh } \\
\text { proses perkuliahan, khususnya tenaga } \\
\text { pengajar yang berhalangan hadir. Jika } \\
\text { Tenaga Pengajar berhalangan hadir, } \\
\text { harus disiapkan Tenaga Pengajar } \\
\text { pengganti atau diisi oleh Branch } \\
\text { Manager / Kepala Bidang dengan materi } \\
\text { motivasi. Tenaga pengganti bertanggung } \\
\text { jawab terhadap rekamannya. }\end{array}$ & $\begin{array}{c}\text { Date }^{1} \text { : } \\
\text { 20.05.201 }\end{array}$ \\
\hline C & 8.2.3 & $\begin{array}{l}\text { Tidak ada bukti } \\
\text { dilakukan monitoring } \\
\text { pencapaian sasaran mutu } \\
\text { Organisasi } 2010 \text { " } \mathrm{D} / \mathrm{O} \\
\text { Mahasiswa max } 5 \% \text { " } \\
\text { (QMR). }\end{array}$ & $\begin{array}{l}\text { Management Representative akan } \\
\text { mempelajari Sasaran Mutu Organisasi } \\
\text { beserta Langkah Pencapaiannya oleh } \\
\text { setiap Direktorat dan membuat } \\
\text { rangkumannya. }\end{array}$ & $\begin{array}{c}\text { Date }^{1} \text { : } \\
12.05 .2011\end{array}$ \\
\hline A & 8.5 .2 & $\begin{array}{lr}\text { Tidak ditemukan bukti } \\
\text { dilakukan } & \text { evaluasi } \\
\text { efektivitas } & \text { terhadap } \\
\text { Tindakan } & \text { Perbaikan } \\
\text { Internal audit } & \text { tanggal } \\
\text { 18/1/2011 } & \text { di } \\
\text { Perpustakaan (QMR). }\end{array}$ & $\begin{array}{l}\text { Seluruh temuan NCR pada Internal Audit } \\
2011 \text { akan dilakukan pembuktiannya } \\
\text { bahwa Tindakan Perbaikan telah } \\
\text { dievaluasi keefektivitasnya. }\end{array}$ & $\begin{array}{c}\text { Date }^{1} \text { : } \\
18.05 .2011\end{array}$ \\
\hline
\end{tabular}

Dari temuan ketidaksesuain (Non Conformance Report) oleh Audit Eksternal dalam periode sertifikasi tiga tahun pertama, LP3I College mengambil manfaat berupa peningkatan sistem manajemen dari segi manajerial maupun teknis yang terangkum dalam Tabel 5, perbaikan redaksional dokumen system manajemen mutu terangkum dalam Tabel 6. Sedangkan temuan yang menunjukkan ketidak-konsistensi (inconsistency) implementasi sistem manajemen mutu terangkum dalam Table 7.

Tabel 5. Manfaat Peningkatan Terhadap Sistem Manajemen Mutu Dari Hasil Temuan Ketidaksesuain oleh Auditor Eksternal

\begin{tabular}{|c|l|}
\hline Plan (5.4.1) & $\begin{array}{l}\text { Setiap Direksi, Eksekutif, Pimpinan Cabang,Kepala Bagian wajib menyusun Sasaran Mutu, } \\
\text { Program Kerja berdasarkan SMART (Specific, Measurement, Applicable, Reasonable dan } \\
\text { Timeline). }\end{array}$ \\
\hline Plan (5.6.2) & $\begin{array}{l}\text { Menjadikan Capaian Sasaran Mutu (Quality objective) sebagai agenda dalam Management } \\
\text { Review dan sebagai agenda setiap Rapat Evaluasi dan Program Kerja Triwulan, Semesteran } \\
\text { dan Tahunan. }\end{array}$ \\
\hline Plan (4.2.4) & $\begin{array}{l}\text { Team IT mempersiapkan program Back up data di seluruh bagian, menjadualkan program } \\
\text { maintenance PC dan Laptop. }\end{array}$ \\
\hline Do (6.3) & $\begin{array}{l}\text { Bagian GA mempersiapkan Program pemeliharaan \& pelaksanaan terhadap prasarana dan } \\
\text { sarana akan dirinci untuk setiap unit prasarana, berikut evaluasi setiap bulan. }\end{array}$ \\
\hline Do (7.1) & $\begin{array}{l}\text { Melakukan evaluasi bagi Kriteria Kelulusan untuk Kemampuan Skills Dasar Khusus pada } \\
\text { saat seleksi penerimaan mahasiswa baru untuk seluruh program College. Misalnya Skills } \\
\text { Dasar Otomotif sebagai prasyarat khusus bagi Program Studi Otomotif, Skills Dasar Logika } \\
\text { sebagai persyaratan khusus Program Study Informatika Komputer Programmer. }\end{array}$ \\
\hline $\begin{array}{l}\text { Check } \\
\text { 8.2.3) }\end{array}$ & $\begin{array}{l}\text { Setiap pimpinan melakukan monitoring terhadap capaian Sasaran Mutu bawahannya dan } \\
\text { melakukan evaluasi up dating Sasaran Mutu. }\end{array}$ \\
\hline Check (8.4) & $\begin{array}{l}\text { Setiap bagian mempersiapkan metoda analisa dan evaluasi terhadap kepuasan pelanggannya, } \\
\text { dan melaksanakan evaluasi per Semesteran dan Tahunan. } \\
\text { Misalnya bagian Cooperation \& Placement (C\&P), pelanggannya adalah Mitra Kerja dan }\end{array}$ \\
\hline
\end{tabular}

Wiwiet Prihatmadji, et.al.( Peningkatan dan Perbaikan dari Temuan Audit External ISO 9001...) 


\begin{tabular}{|c|l|}
\hline & Alumni, bagian pendidikan pelangganya adalah mahasiswa dan orangtua. \\
\hline Act (8.5.2) & $\begin{array}{l}\text { Seluruh temuan Non Conformance Report (NCR) pada Internal Audit selalu dikontrol } \\
\text { pembuktiannya bahwa Tindakan Perbaikan telah dievaluasi keefektivitasnya. }\end{array}$ \\
\hline Act (8.5.2) & $\begin{array}{l}\text { Membuat tindakan perbaikan / corrective action terhadap setiap ketidaktercapaian sasaran } \\
\text { mutu di Rapat Evaluasi dan Program Kerja Triwulan, Semesteran dan Tahunan. }\end{array}$ \\
\hline
\end{tabular}

Tabel 6. Perbaikan Terhadap Sistem Manajemen Mutu Dari Hasil Temuan Ketidaksesuain oleh Auditor Eksternal

\begin{tabular}{|c|l|}
\hline Plan (4.2.3) & $\begin{array}{l}\text { Melakukan validasi dokumen, baik dokumen internal maupun eksternal, yang ditandai / } \\
\text { diberikan tanda cap Validasi Dokument. Untuk dokumen yang tidak berlaku lagi diberi tanda } \\
\text { pengenal dengan cap Expired Document. }\end{array}$ \\
\hline Plan (4.2.3) & $\begin{array}{l}\text { Melakukan pemeriksaan ulang (re-check) terhadap isi (content) SOP edisi tahun } 2012 \\
\text { terhadap kesalahan rekasional isinya kata demi kata, data yang dikemukakan, dan formulir } \\
\text { yang dilampirkan }\end{array}$ \\
\hline Plan (7.4.1) & Mempersiapkan Prosedur Evaluasi Pelaksanaan Kegiatan Penunjang (Outsourcing). \\
\hline Do (7.4.1) & $\begin{array}{l}\text { Merevisi redaksi Evaluasi Supplier menjadi tanggung jawab pimpinan setiap bidang yang } \\
\text { menjalankan proses pembelian dan pengadaan barang, bukan lagi menjadi tanggung jawab } \\
\text { Finance Director }\end{array}$ \\
\hline $\begin{array}{l}\text { Check } \\
\text { (8.2.2) }\end{array}$ & $\begin{array}{l}\text { Menggunakan temuan observasi dari Auditor Eksternal sebagai Saran Auditor atau alternatif } \\
\text { perbaikan terhadap sistem manajemen mutu. }\end{array}$ \\
\hline
\end{tabular}

Tabel 7. Perbaikan Terhadap Ketidak-konsistensi (inconcistency) Sistem Manajemen Mutu Dari Hasil Temuan Ketidaksesuain oleh Auditor Eksternal

\begin{tabular}{|c|l|}
\hline Plan (6.2.2) & $\begin{array}{l}\text { HRD melakukan mapping setiap pejabat dengan kompetensi yang dipersyaratkan, dan } \\
\text { membuat program untuk meningkatkan kompetensi pejabat terkait yang tidak memenuhi } \\
\text { persyaratan. }\end{array}$ \\
\hline Do (7.5.1) & $\begin{array}{l}\text { Lembaga melakukan evaluasi terhadap seluruh proses perkuliahan, khususnya tenaga } \\
\text { pengajar yang berhalangan hadir. Jika Tenaga Pengajar berhalangan hadir, harus disiapkan } \\
\text { Tenaga Pengajar pengganti atau diisi oleh Branch Manager / Kepala Bidang dengan materi } \\
\text { motivasi. Tenaga pengganti bertanggung jawab terhadap rekamannya. }\end{array}$ \\
\hline
\end{tabular}

\section{KESIMPULAN}

Temuan audit eksternal yang memberikan manfaat langsung untuk peningkatan sistem manajemen mutu di LP3I College dengan uraian methodology PDCA sebagai berikut:

Plan : (1) Manajemen menyusun sasaran mutu (quality objective) berdasarkan SMART yaitu Specific, Measurement, Applicable, Reasonable dan Timeline (5.4.1) dan (2) capaian sasaran mutu ditetapkan sebagai agenda dalam Management Review dan sebagai agenda setiap Rapat Evaluasi dan Program Kerja Triwulan, Semesteran dan Tahunan (5.6.2). (3) Team IT mempersiapkan program Back up data di seluruh bagian, menjadualkan program maintenance PC dan Laptop (4.2.4).

Do : (1) Program pemeliharaan dan realisasi target terhadap prasarana dan sarana oleh bagian GA dievaluasi setiap bulan (6.3), (2) Kemampuan Skills Dasar Khusus ditetapkan sebagai rujukan bagi Kriteria Kelulusan pada saat seleksi penerimaan mahasiswa baru untuk seluruh program College (7.1). 
Check : (1) Setiap pimpinan melakukan monitoring dan evaluasi terhadap capaian Sasaran Mutu bawahannya (8.2.3), (2) Setiap bagian mempersiapkan metoda analisa dan evaluasi terhadap kepuasan pelanggannya, serta melaksanakan evaluasi per Semesteran dan Tahunan (8.4).

Act

: Setiap bagian membuat evaluasi terhadap efektivitas Tindakan Perbaikan dari temuan Non Conformance Report (NCR) pada setiap proses audit (8.5.2), (2) dan membuat tindakan perbaikan / correctiv action terhadap setiap ketidakcapaian sasaran mutu di Rapat Evaluasi dan Program Kerja Triwulan, Semesteran dan Tahunan (8.5.2).

Perbaikan dalam implementasi SMM sebagai solusi dari temuan oleh auditor dalam kasus (1) ketidaksesuaian pelaksanaan standar internal (SOP dan Quality Manual ISO 9001 LP3I College ) dengan standar baku (ISO $9001 \mathrm{BSN}$ ) sebagai berikut, tiga kasus Plan: validasi dokumen (4.2.3), pemeriksaan ulang (re-check) terhadap isi (content) SOP edisi tahun 2012 (4.2.3), dan Mempersiapkan Prosedur Evaluasi Pelaksanaan Kegiatan "Outsourcing" (7.4.1). Untuk siklus Do: menetapkan evaluasi supplier menjadi tanggung jawab pimpinan setiap bidang yang menjalankan proses pembelian dan pengadaan barang (7.4.1). Sedangkan siklus Check: menetapkan bahwa temuan observasi dari Auditor Eksternal dimasukkan sebagai Saran Auditor atau alternatif perbaikan terhadap sistem manajemen mutu (8.2.2).

(2) tidak kosisten (inconsistency) dalam menjalankan prosedur meliputi, Plan: mapping setiap pejabat sesuai dengan kompetensinya (6.2.2), dan $D o$ : evaluasi terhadap seluruh proses perkuliahan dan rekamannya (7.5.1).

\section{SARAN}

1. Peningkatan sistem manjemen mutu yang diperoleh dari hasil implementasi ISO 9001 selama tiga tahun berturut-turut hendaknya dipertahankan dan ditingkatkan melalui sharing experiences dari perusahaan lain, atau melalui cara lain yang baik.

2. Proses audit mutu oleh pihak eksternal hendaknya menjadi media pelatihan atau workshop proses audit mutu internal oleh pihak institusi seperti manajemen audit, teknis audit, kompetensi auditor, dan persiapan auditee.

3. Perlu dilakukan penelitian lanjutan dengan topik yang sama untuk impelementasi ISO 9001 pada periode tiga tahun berikutnya.

\section{DAFTAR PUSTAKA}

Ann Terlaak and Andrew A. King, 2012, The Effect of Certification With The ISO 9000 Quality Management Standard: A Signing Approach, Journal of Economic Behavior and Organization, Vol. 5, No. 1, page 29-43

Columbus, G (2000) Record Management Manual (5th edition), Washington: Memorial Library Publishing.

Diaye et.al, 2018, Difficulties in ISO 9001 implementation in Manufacturing and Service Organizations: Empirical Evidence from Serbia-Montenegro, International Journal for Quality Research, Vol.2, No. 1, page 35-41.

Graeme Knowles (2011) Quality Management, London: GK \& N Publishing

Hendartho, Dony, 2014, “Analisis Implementasi Sistem Manajemen Mutu ISO 9001:2008 pada STIAMI", Jurnal Transparansi, Volume VI, Nomor 02, Hal. 124-138.

ISO 9000:2005, Quality management systems - Fundamentals and vocabulary diadopsi menjadi SNI 199000-2008 Sistem manajemen mutu - Dasar-dasar dan kosa kata.

ISO 9004:2000, Quality management systems - Guidelines for performance improvements diadopsi menjadi SNI 19-9004-2002 Sistem manajemen mutu - Panduan untuk perbaikan kinerja 
ISO 19011:2002, Guidelines for quality and/or environmental management systems auditing diadopsi menjadi SNI 19-19011-2005 Panduan audit sistem manajemen mutu dan/atau lingkungan

ISO Secretariat (2015), Correlation Matrices Between ISO 9001:2008 and ISO 9001:2015, Vienna, ISO Publishser.

ISO Secretariat (2009), ISO 9000 and Selection for Use, Vienna, ISO Publishser.

Nurdin and Prihatmadji, 2017, "Kesesuaian Dokumentasi di LP3I College Jakarta dengan Sistem Manajemen Mutu ISO 9001:2008”, Jurnal Lentera Bisnis Politeknik LP3I Jakarta, Vol. 6. No.14. Hal. 131-141.

Prihatmadji, Wiwiet, 2014, "Implementasi Sistem Manajemen Mutu ISO 9001:2008 pada LP3I College Jakarta”, Jurnal Lentera Bisnis Politeknik LP3I Jakarta, Vol. 1. No. 4. Hal. 145-173.

M. Sokovic, D. Pavletic, and K. Kern Pipan, 2010, Quality Improvement Methodologies - PDCA Cycle, RADAR Matrix, DMAIC and DFSS, Journal of Achievements in Materials and Manufacturing Engineering, 43/1, page 476-483.

National Security Inspectorate UK (2016), PDCA Cycle on ISO 9001, NSI Publisher, London UK.

Naukowe, Zeszyty, 2012, Effectiveness of planning internal audits of the quality system, Scientific Journals, 32(104), page 48-54

Nurcahyo and Sumaedi, 2011, Study On Implementation of ISO 9001 in Higher Education XYZ on Administration Services, Jurnal Standardisasi Vol. 13, No. 3, page 155 - 162.

Rogala, Piotr, 2015, Quality Audits in Municipality Offices - Evidence From Poland, Proceeding of Managing Intellectual Capital and Innovation for Sustainable Capital, Bari Italy, page 2169-2174,.

Rogala, Piotr, 2015, Why Do Internal Audits Fail ? The Internal Auditors Perspective, $9^{\text {th }}$ International Quality Conference at University of Kragujevac, page 367-374.

Santos, Gilberto and Millán, António Leal, 2015, Motivation and Benefits of Implementation and Certification According ISO 9001 - The Portuguese Experience, International Journal for Quality Research 7(1) 71-86. 